\title{
POLA PERGERAKAN WISATAWAN PADA KAWASAN PARIWISATA PANTAI KOTA MAKASSAR
}

\author{
Wasilah $^{1}$, Andi Hildayanti ${ }^{2}$ \\ 1 Jurusan Arsitektur, Fakultas Sains dan Teknologi, UIN Alauddin Makassar \\ 2 Jurusan Arsitektur Fakultas Sains dan Teknologi, UIN Alauddin Makassar \\ Jl. H.M. Yasin Limpo No.36, Romangpolong-Gowa \\ *Email:wasilah@uin-alauddin.ac.id
}

\begin{abstract}
ABSTRAK
The city of Makassar has the advantage of a charming beach tourism destination and is an icon of the city located in the Losari Beach Region or known as the CPI Region (Center point of Indonesia). Losari beach area has zoning areas consisting of tourist areas namely Losari Beach Pavilion, Fort Rotterdam, Shopping Center and Ole-ole Somba Opu, and Culinary Tourism Areas that are expected to attract tourists to visit. However, visitor / tourist movements are concentrated only on the Losari Beach Pavilion. Through the cognitive mapping analysis method, this study aims to identify the characteristics of movement patterns of tourists in the Losari Beach tourism area and the factors that influence the pattern of tourist movements. The pattern of tourist movements is obtained from the recapitulation of index cards based on tourist routes. The results of this study are that the tourist movement pattern is dominated by a single point pattern with the tourist destinations of Losari Beach Pavilion and the least movement patterns carried out by tourists is the Chaining Loop pattern which visits four tourist spots namely Losari Beach Pavilion, Culinary Center for street vendors, Makassar, Fort Rotterdam, and Makassar Ole-Ole shopping center, and factors that influence tourist movement patterns are the classification of tourist interest, operational time and classification based on the ease of tourist movements.
\end{abstract}

Keywords: Cognitive Mapping, Losari Beach Area, Movement Pattern, Tourists.

\section{PENDAHULUAN}

Karakteristik suatu tempat dalam hal pemanfaatan suatu lingkungan binaan tertentu bukan hanya sekedar mewadahi kegiatan fungsional secara statis, melainkan menyerap dan menghasilkan makna berbagai kekhasan suatu tempat antara lain setting fisik bangunan, komposisi dan konfigurasi bangunan dengan ruang publik serta kehidupan masyarakat setempat [1][2]. Salah satunya adalah kawasan pariwisata yang memiliki setting fisik dan konfigurasi bangunan yang beragam.

Destinasi Pariwisata adalah area atau kawasan geografis yang berbeda dalam suatu atau lebih wilayah administratif yang di dalamnya terdapat unsur: daya tarik wisata, fasilitas pariwisata, aksesibilitas, masyarakat serta wisatawan yang saling terkait dan melengkapi untuk terwujudnya kegiatan kepariwisataan [3][4].
Daya tarik yang tidak atau belum dikembangankan merupakan sumber daya potensial dan belum dapat disebut daya tarik wisata, sampai adanya suatu jenis pengembangan tertentu [5]. Objek dan daya tarik wisata merupakan dasar bagi kepariwisataan. Tanpa adanya daya tarik di suatu daerah atau tempat tertentu kepariwisataan sulit untuk dikembangkan [5][6].

Kota Makassar merupakan kota yang terletak di wilayah pesisir barat propinsi Sulawesi Selatan dan sebagai ibukota Provinsi serta pintu gerbang kawasan Indonesia Timur. Infrastruktur sarana prasarana pendukung kegiatan pariwisata yang tersedia antara lain, hotel berbintang dan tempat hiburan yang representatif, pusat perbelanjaan serta sarana olahraga [7]. Jenis kegiatan wisata yang dapat dijumpai antara lain wisata pesisir, sejarah, budaya, dan wisata konvensi atau MICE (meeting, incentive, conference, exhibition). Uraian di atas menunjukkan bahwa Kota 
Makassar memiliki potensi industri pariwisata yang sangat baik untuk dikembangkan.

Kawasan wisata di Sulawesi Selatan sebagai salah satu aset pariwisata yang perlu diperhatikan mengingat kawasan wisata memiliki daya tarik alami yang tidak dimiliki oleh obyek wisata sejenis. Penanganan yang profesional atas aset pariwisata ini juga perlu ditingkatkan terutama perencanaan dan penataan yang berwawasan alam dan budaya.

Menurut Spillane (1987), peranan pariwisata dalam pembangunan negara pada garis besarnya berintikan tiga segi, yaitu segi ekonomis (sumber devisa, pajak-pajak), segi sosial (penciptaan lapangan kerja), dan segi kebudayaan (memperkenalkan kebudayan kita kepada wisatawan-wisatawan asing) [8].

Kawasan pariwisata yang terkenal di Sulawesi Selatan salah satunya adalah kawasan wisata pantai losari. Kawasan ini memiliki banyak spot wisata seperti, Anjungan Pantai Losari, Fort Rotterdam , Pusat Perbelanjaan Somba Opu, Kawasan Kuliner Kota Makassar dan Sentra PKL Jajanan Kuliner yang juga menyajikan beragam atraksi wisata, namun yang selama ini dikenal oleh masyarakat luas dan menjadi ikon kota Makassar yaitu Anjungan Pantai Losari berupa ruang terbuka publik dengan beberapa fasilitas penunjang didalamnya yang memadai.

Komponen spasial ruang yang berperan dalam koneksi fungsi dalam kawasan adalah sirkulasi/jalan. Elemen sirkulasi adalah satu aspek yang kuat dalam membentuk struktur lingkungan perkotaan, tiga prinsip utama pengaturan teknik sirkulasi adalah jalan harus menjadi elemen ruang terbuka yang memiliki dampak visual yang positif, Jalan harus dapat memberikan orientasi kepada pengemudi dan membuat lingkungan menjadi jelas terbaca, serta sektor publik harus terpadu dan saling bekerjasama untuk mencapai tujuan bersama.

Disamping itu, keberadaan jalur pejalan kaki ternyata mampu menentukan tujuan kunjungan wisatawan sehingga komponen ini menjadi suatu objek vital dalam menunjang optimalisasi fungsi kawasan pariwisata. Sistem pejalan kaki yang baik mampu mengurangi ketergantungan dari kendaraan bermotor dalam areal kota, meningkatkan kualitas lingkungan dengan memprioritaskan skala manusia, dan lebih mengekspresikan aktifitas PKL mampu menyajikan kualitas udara.
Permasalahan utama yang terjadi pada kawasan pariwisata pantai Losari adalah kurangnya wisatawan yang berkunjung ke area wisata disekitar kawasan Pantai Losari dikarenakan kondisi aksesibilitas yang belum terhubung dengan baik, adanya kemacetan di berbagai ruas jalan dalam kawasan Pantai Losari, moda transportasi yang belum memadai bagi wisatawan untuk mengunjungi area wisata, serta belum optimalnya fasilitas pejalan kaki serta masih kurangnya fasilitas parkir pada beberapa spot wisata. Kondisi ini mengakibatkan kurangnya motivasi wisatawan dalam melakukan perjalanan wisata dengan mengunjungi area wisata dalam Kawasan Pantai Losari.

Oleh karena itu penelitian ini bertujuan untuk memahami pergerakan wisatawan sehingga dalam penataan kawasan pariwisata yang dapat mendukung pengembangan manajemen pariwisata, perencanaan sarana dan prasarana wisata, pengembangan produk pariwisata, dan pemasaran daya tarik pariwisata yang dapat meningkatkan motivasi wisatawan untuk melakukan perjalanan wisata dan meningkatkan pendapatan daerah Kota Makassar.

\section{METODE PENELITIAN}

Metode penelitian yang digunakan dalam studi ini adalah termasuk dalam metode penelitian deskriptif (descriptive research) dengan teknik pengumpulan data : studi pustaka, observasi, wawancara mendalam dan melalui penyebaran index card dengan aspek yang ditinjau yaitu pola pergerakan, daya tarik dan harapan wisatawan.

Responden dalam penelitian merupakan sampel masyarakat atau pendatang yang berkunjung ke tiap spot wisata pada kawasan Pantai Losari, dimana pemilihan Responden melalui teknik non probabilitas sampling berdasarkan kebetulan /insidental bertemu dengan peneliti dan kriteria minimal berusia 17 tahun.

Metode Analisis yang digunakan adalah Cognitive Mapping atau metode analisa kognitif spasial yang dirumuskan sebagai bentuk analisis urban design (Urban Design Toolkit MFE, 2006).

Metode analisa ini dibagi menjadi empat langkah, yaitu:

a. Langkah pertama yaitu melakukan pengamatan di lapangan terhadap pola 
pergerakan wisatawan dalam kawasan Pantai Losari.

b. Mengaitkan pengamatan dengan persepsi wisatawan melalui index card guna mendukung hasil pengamatan oleh peneliti.

c. Melakukan analisis pola pergerakan wisatawan antar spot wisata serta daya tarik wisatawan berkunjung dalam overlay mapping guna mengetahui kecenderungan wisatawan dalam melakukan aktivitas wisata dan factorfaktor yang mempengaruhi pola pergerakan wisatawan

d. Menarik kesimpulan karakeristik pola pergerakan wisatawan.

Adapun kategori pola pergerakan wisatawan dengan sketsa yang sederhana dikemukakan Lau dan McKercher (2006) dalam jurnal Understanding Tourist Movement Pattern In a Destination: A GIS Approach [9] dapat dilihat pada tabel 1 sebagai berikut:

Tabel 1. Pola Pergerakan Wisatawan dengan

Sketsa Sederhana

\begin{tabular}{|c|c|}
\hline Pola Pergerakan & Deskripsi \\
\hline I.Single Pattern & Tidak \\
\hline Single Point & pergerakan dalam proses \\
\hline & kunjungan ke destinasi. \\
\hline & Wisatawan berkunjung \\
\hline & satu destinasi dan kembali \\
\hline & $\begin{array}{l}\text { ke tempat asalnya dengan } \\
\text { rute yang sama }\end{array}$ \\
\hline \multirow[t]{2}{*}{ Multiple Pattern } & Pola pergerakan \\
\hline & wisatawan dimulai dari \\
\hline \multirow[t]{4}{*}{ Base Site } & tempat asalnya ke \\
\hline & dilanjutkan ke destinasi \\
\hline & sekunder dalam pola \\
\hline & $\begin{array}{l}\text { pergerakan ini dapat lebih } \\
\text { dari satu destinasi. }\end{array}$ \\
\hline \multirow{8}{*}{ StopOver } & pergerakan \\
\hline & wisatawan dengan fokus \\
\hline & $\begin{array}{ll}\text { menuju destinasi utama } \\
\text { dimana }\end{array}$ \\
\hline & $\begin{array}{l}\text { perjalanannya } \\
\text { mengunjungi }\end{array}$ \\
\hline & destinasi sekunder yang \\
\hline & $\begin{array}{l}\text { menarik dan dikunjungi } \\
\text { wisatawan. }\end{array}$ \\
\hline & pergerakan. \\
\hline & wisatawan \\
\hline
\end{tabular}

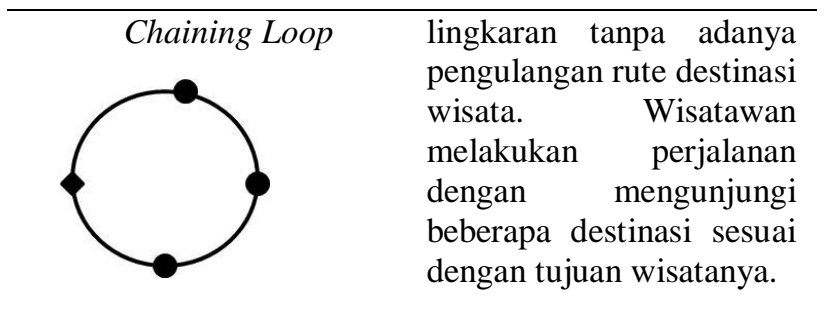

Complex Pattern
Destination
wegatawan yang dimulai
dengan rute mengelilingi
destinasi lainnya.
Setelah menyelesaikan
tur secara berkeliling
(pola lingkaran), mereka
kembali ke tempat asal
melalui rute yang paling
singkat antara tujuan
utama dan tempat asal
berangkat. Ini
merupakan kombinasi
daripola single point dan
chaining loop.

Complex
kembinasi dua atau lebih
pola-pola yang telah
disebutkan diatas

\section{HASIL DAN PEMBAHASAN}

Berdasarkan pola pergerakan wisatawan yang dikemukakan Lau dan McKercher (2006), ternyata teridentifikasi seluruh pola pergerakan wisatawan terjadi di Kawasan Pariwisata Pantai Losari. Hasil wawancara yang telah dilakukan menunjukkan sebagian besar responden lebih memilih menggunakan kendaraan pribadi untuk mengunjungi area wisata dalam kawasan Pantai Losari, karena pertimbangan kemudahan dan akses yang lebih cepat untuk mengunjungi setiap spot wisata di kawasan tersebut.

Pantai Losari terletak di lokasi yang strategis karena berada dalam simpul jalan, sehingga dapat diakses dari beberapa arah. Pantai Losari dapat diakses dari Jalan Penghibur di sebelah selatan yang memudahkan mencapai Anjungan Pantai Losari dan terdapat parkir komunal yang memudahkan wisatawan untuk parkir kendaraan, serta akses masuk 
kedua dari arah utara yaitu Jalan Ujung Pandang yang memudahkan langsung ke Fort Rotterdam yang juga memiliki parkir komunal. Berdasarkan ragam pola pergerakan yang dikemukakan oleh Gigi Lau dan Bob McKercher (2006) dibagi menjadi 6 jenis pola pergerakan yaitu single point, base site, stopover, chaining loop, destination region loop dan complex neighbourhood [4]. Mengacu pada teori tersebut, pola pergerakan wisatawan dibagi menjadi 3 jenis yaitu single pattern, multiple pattern, dan complex pattern.

Hasil rekapitulasi index card yang telah dilakukan pada 20 Wisatawan dalam Kawasan Pantai Losari, terdapat beberapa pola pergerakan wisatawan terhadap beberapa spot wisata berdasarkan rute wisatawan, adapun pola pergerakan wisatawan sebagai berikut:

\section{Single Point}

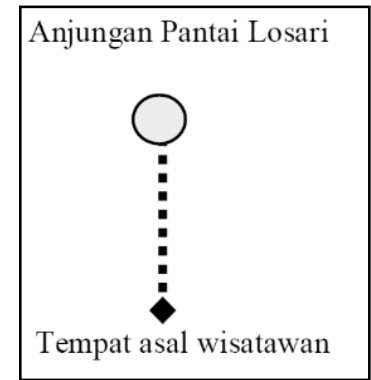

Gambar 1. Pola single point

Pola Pergerakan single point (lihat gambar 1) yang menuju hanya satu titik destinasi tanpa mengunjungi titik destinasi lain dan kembali ke tempat asal yaitu pola pergerakan destinasi wisatawan yang hanya mengunjungi Anjungan Pantai Losari dan wisatawan yang hanya mengunjungi Fort Rotterdam (lihat gambar 2) .

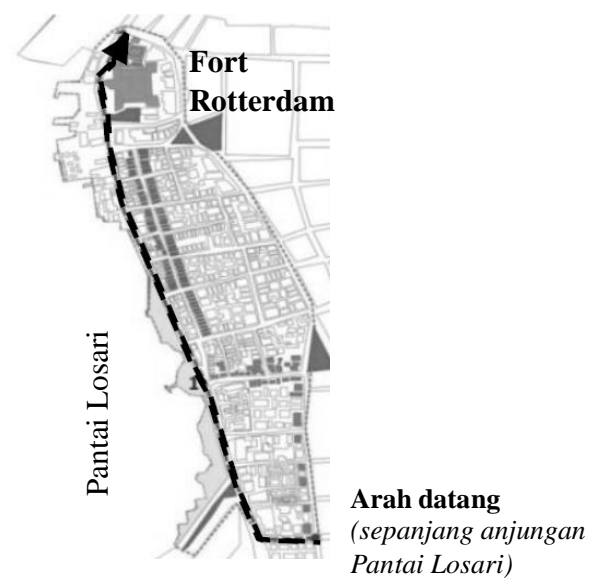

Gambar 2. Pola Single point yang terjadi di objek penelitian

Berdasarkan data index card yang disebarkan dilokasi penelitian, diketahui sebanyak 12 responden hanya mengunjungi satu spot wisata dengan rincian 8 wisatawan hanya mengunjungi anjungan pantai losari untuk menikmati sunset sambil kuliner dijajaran pedagang kaki lima yang berkeliling disekitar anjungan, sedangkan 4 wisatawan mengunjungi Fort Rotterdam untuk sekedar berfoto dan melakukan diskusi rutin dengan organisasinya. Sebagian besar wisatawan yang melakukan pola single point merupakan masyarakat lokal dengan rentan usia 14 tahun hingga 29 tahun.

\section{Base Site}

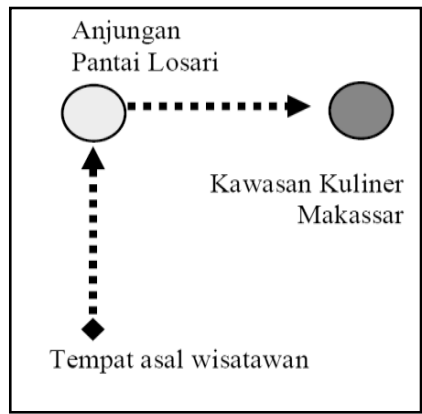

Gambar 3. Pola base site

Pada pola pergerakan base site (lihat gambar 3), wisatawan memulai perjalanan dari tempat asal dan menuju ke tujuan utama dan dilanjutkan melakukan kunjungan ke tujuan sekunder dalam wilayah tertentu yaitu pola pergerakan destinasi wisatawan dari tempat asalnya lalu mengunjungi Anjungan Pantai Losari ke Fort Rotterdam dan wisatawan yang mengunjungi Anjungan Pantai Losari ke Kawasan Kuliner Makassar dengan Anjungan Pantai Losari sebagai atraksi utama (lihat gambar 4). 


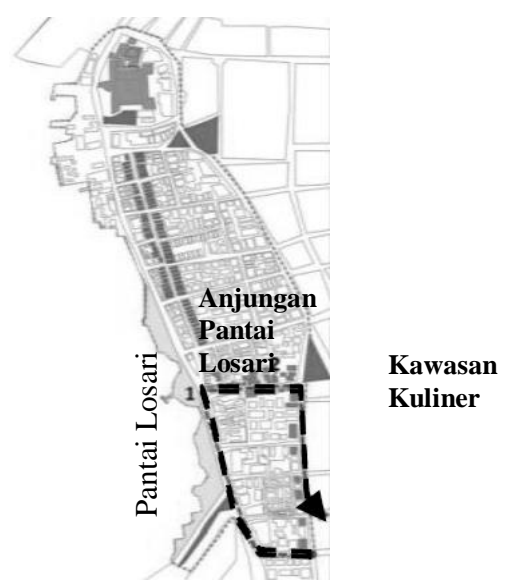

Gambar 4. Pola Base side yang terjadi di objek penelitian

Berdasarkan data index card yang disebarkan diketahui sebanyak 5 responden dengan rincian 3 responden mengunjungi anjungan Pantai Losari dan ketika malam hari mereka melanjutkan kunjungannya ke kawasan kuliner yang terletak tidak jauh dari anjungan Pantai Losari untuk memikmati hidangan makan malam khas Makassar, sedangkan 2 responden lainnya mengunjungi Anjungan Pantai Losari kemudian melanjutkan kunjungan ke Fort Rotterdam . Sebagian besar wisatawan yang melakukan pola base site merupakan masyarakat lokal dengan rentan usia 24 tahun hingga 41 tahun.

\section{Stopover}

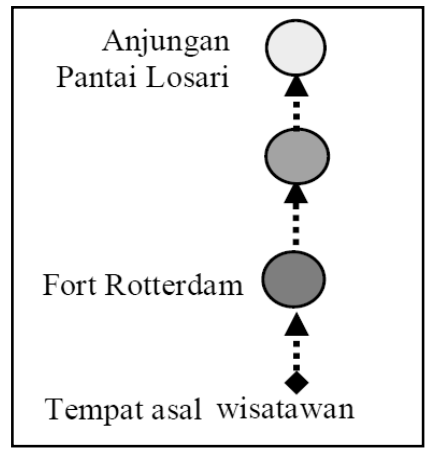

Gambar 5. Pola Stopover

Pada pola pergerakan Stopover (lihat gambar 5), pergerakan yang menuju satu titik destinasi utama dimana mengunjungi titik destinasi lain (sekunder) dalam proses pergerakannya yaitu pola pergerakan wisatawan dengan dua destinasi wisata atau lebih dari Fort Rotterdam -Pusat ole ole Kota Makassar -
Anjungan Pantai Losari, dimana Fort Rotterdam dan Pusat ole ole sebagai destinasi sekunder dan Anjungan Pantai Losari merupakan destinasi utama (lihat gambar 6).

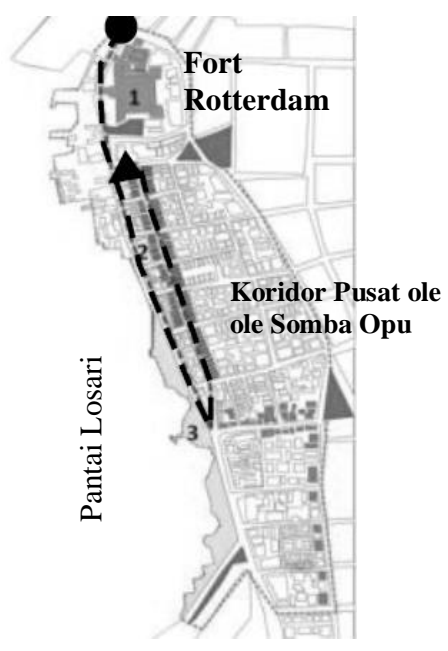

Gambar 6. Pola Stopover yang terjadi di objek penelitian

Berdasarkan data index card yang disebarkan diketahui sebanyak 2 responden mengunjungi Fort Rotterdam kemudian menuju Pusat ole ole Kota Makassar dan mengakhiri kunjungan di anjungan Pantai Losari untuk menikmati panorama laut di malam hari. Wisatawan yang melakukan pola stopover merupakan masyarakat lokal dengan rentan usia 25 tahun dan 27 tahun.

\section{Chaining Loop}

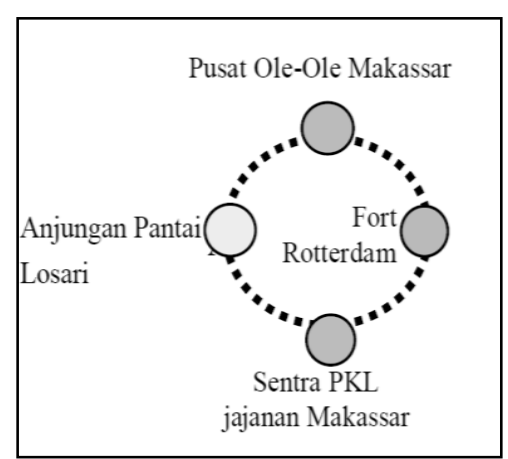

Gambar 7. Pola Chaining Loop

Pada Pola Pergerakan Chaining Loop dengan tipe memutar seperti cincin (lihat gambar 7) yang menghubungkan 2 atau lebih titik destinasi dan tidak terjadi pengulangan rute, yaitu pola pergerakan wisatawan dengan 4 destinasi wisata yang dimulai dari Fort 
Rotterdam - Anjungan Pantai Losari - Sentra PKL Jajanan Makassar - Pusat Ole-Ole Makassar dan setelah itu wisatawan langsung kembali ke asalnya (lihat gambar 8).

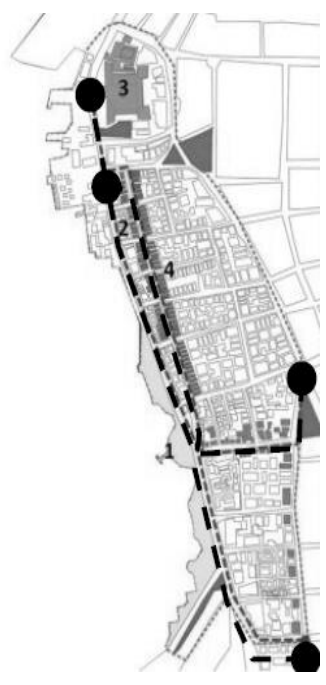

Gambar 8. Pola Chaining Loop yang terjadi di objek penelitian

Berdasarkan data index card yang disebarkan diketahui sebanyak 1 responden mengunjungi Fort Rotterdam kemudian menuju Anjungan Pantai Losari setelah itu mereka mengunjungi Sentra PKL Jajanan Makassar dan Pusat Ole-Ole Makassar. Berdasarkan data daerah asal, responden tersebut berasal dari luar provinsi Sulawesi Selatan. Wisatawan yang melakukan pola chaining loop merupakan pengunjung domestik dengan rentan usia 38 tahun.

Berdasarkan keempat pola tersebut, diketahui bahwa pola pergerakan wisatawan hanya dua macam yaitu single pattern dan multiple pattern. Pada pola pergerakan single point, destinasi wisatawan dominan mengunjungi Anjungan Pantai Losari dan selanjutnya adalah Fort Rotterdam . Pada pola pergerakan base site dengan dua destinasi wisata didominasi pola pergerakan dari Anjungan Pantai Losari ke Fort Rotterdam dan dari Anjungan Pantai Losari ke Kawasan Kuliner Makassar dengan Anjungan Pantai Losari sebagai atraksi utama. Untuk pola pergerakan stopover dengan dua destinasi wisata atau lebih didominasi pola pergerakan dari Fort Rotterdam - Sentra PKL Jajanan Makassar - Anjungan Pantai Losari, dan untuk pola pergerakan chaining loop dengan 4 destinasi wisata didominasi pola pergerakan Fort Rotterdam - Anjungan Pantai Losari -
Sentra PKL Jajanan Makassar -Pusat Ole-Ole Makassar dimana wisatawan langsung kembali ke tempat asalnya.

Berikut ini pada gambar 9 menunjukkan persentase kunjungan wisatawan berdasarkan pola pergerakan wisatawan di lokasi penelitian.

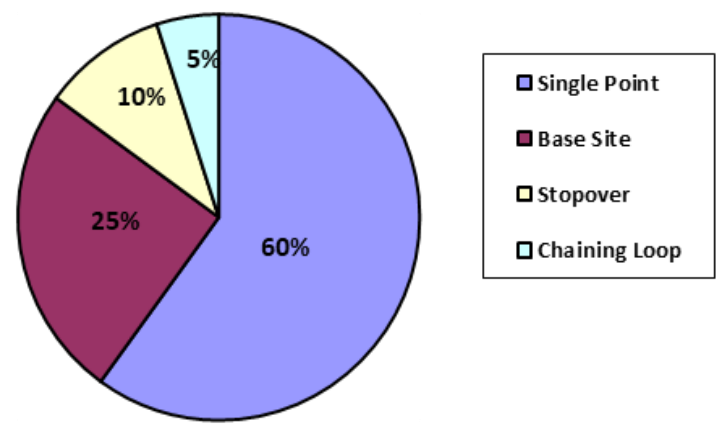

Gambar 9. Persentase jumlah responden tiap pola pergerakan menurut Lau dan McKercher (2006)

Dari semua jenis pola pergerakan yang dilakukan wisatawan, jenis pola pergerakan single point yang paling didominasi dalam kawasan Pantai Losari dan jenis pola chaining loop adalah pola pergerakan yang sedikit dilakukan wisatawan. Untuk jumlah destinasi wisata yang dikunjungi wisatawan adalah juga didominasi oleh satu destinasi wisatawan dan yang paling sedikit mengunjungi empat destinasi wisata dalam kawasan Pantai Losari.

Sebagian besar daya tarik wisatawan untuk berkunjung ke Kawasan Pantai Losari untuk melihat landmark Kota Makassar yaitu Pantai Losari, dimana menawarkan keindahan alam dan miniatur-miniatur kebudayaan yang menarik pengunjung untuk berekreasi, berinteraksi sosial dan bersantai.

Berdasarkan persepsi wisatawan tersebut diketahui bahwa spot wisata Anjungan Pantai Losari lebih menarik wisatawan untuk berkunjung dikarenakan menyajikan atraksi wisata yang beragam, yang kedua adalah pada spot wisata Fort Rotterdam juga menarik wisatawan untuk berkunjung dikarenakan bangunan peninggalan sejarah yang tidak bisa didapatkan di daerah manapun selain di kawasan Pantai Losari, ketiga adalah spot wisata Sentra PKL dan Kawasan Kuliner Makassar dimana wisatawan dapat menikmati kuliner Makassar sambil menikmati keindahan pantai dan yang terakhir adalah Pusat Ole-Ole Makassar yang merupakan pusat ole-ole 
terbesar di Makassar. Berikut ini persentase faktor kunjungan wisatawan.

Dari pola pergerakan yang dilakukan wisatawan, terdapat beberapa faktor yang mempengaruhi pola pergerakan wisatawan berdasarkan hasil wawancara yang telah dilakukan pada 20 wisatawan sebagai berikut:

\section{Ketertarikan Atraksi Wisata}

Keterikatan antar spot wisata yang ditentukan dari urutan spot wisata yang dikunjungi pertama lalu berkunjung ke spot wisata lainnya dipengaruhi oleh minat wisatawan terhadap atraksi wisata yang terdapat pada spot wisata. Setiap wisatawan memiliki minat yang berbeda terhadap tiap atraksi wisata yang disajikan pada spot wisata walaupun tidak sepenuhnya atraksi wisata yang disajikan tiap spot wisata diminati oleh wisatawan, bahkan dominan wisatawan yang memiliki minat sajian wisata keindahan pantai memilih untuk tetap di satu spot wisata saja yaitu Anjungan Pantai Losari tanpa melakukan kunjungan ke wisata lainnya, begitu pula pada minat wisatawan terhadap bangunan peninggalan sejarah lebih memilih untuk tetap di satu spot wisata saja yaitu Fort Rotterdam .

Fort rotterdam memiliki daya tarik berupa pengalaman ruang bersejarah dan ketersediaan ruang publik yang memadai untuk aktivitas ruang luar. Ruang terbuka publik akan menjadi penting bagi seseorang, bila tempat tersebut memiliki beberapa fasilitas pendukung yang dapat mengakomodasi kebutuhan orang dalam beraktifitas [10]. Terletak di tepi pantai dengan fasilitas penunjang disekitarnya mampu menarik wisatawan untuk berkunjung. Kegiatan yang berlangsung didalamnya cukup beragam. Seperti festival kuliner, festival musik, dan kegiatan organisasi lainnya.

Dari kondisi tersebut maka dapat disimpulkan bahwa keterikatan antar spot wisata yang terjadi adalah pola bebas dimana keterikatan antar spot wisata tidak ditentukan berdasarkan urutan atau sekuel melainkan berdasarkan minat wisatawan terhadap atraksi wisata yang disajikan.

\section{Waktu Operasional}

Beberapa spot wisata hanya buka pada pagi hari - sore hari adalah Benteng Fort Rotterdam dan Pusat Ole-Ole Makassar sehingga membatasi kunjungan wisatawan hanya pada waktu operasional, sedangkan spot wisata yang aktif sepanjang hari adalah Anjungan Pantai Losari yang tidak memiliki batas waktu kunjungan. Beberapa wisatawan memilih mengunjungi Anjungan Pantai Losari pada saat matahari terbit dan tenggelam untuk menikmati keindahan sunset dan sunrise, dan beberapa wisatawan lainnya memilih untuk lebih dulu mengunjungi Fort Rotterdam dengan waktu operasional yang terbatas namun banyak atraksi yang disajikan.

Dari kondisi tersebut maka dapat disimpulkan bahwa keterikatan antar spot wisata yang terjadi adalah pola campuran dimana kunjungan wisatawan didasari pada waktu operasional tiap spot wisata dan waktu yang tepat dalam mengunjungi tiap spot wisata.

\section{KESIMPULAN}

Pola pergerakan wisatawan cukup beragam dan didominasi dengan pola single pattern yang mengunjungi satu destinasi wisata (single point) yang mengunjungi satu spot wisata, dengan objek kunjungan dominan adalah anjungan Pantai Losari.

Pola stopover dan chaining loop kurang dilakukan oleh wisatawan dengan alasan jarak antara spot wisata Fort Rotterdam dan anjungan pantai losari yang cukup jauh, serta fasilitas penjalan kaki yang tidak memadai. Parkir komunal tidak tersedia disetiap spot wisata sehingga pola single point menjadi pilihan pergerakan kebanyakan wisatawan.

Pada dasarnya pola pergerakan wisatawan dipengaruhi beberapa faktor yaitu klasifikasi minat wisatawan terhadap atraksi wisata pada spot wisata, waktu operasional tiap spot wisata, dan klasifikasi berdasarkan kemudahan pergerakan wisatawan. Adapun kesan wisatawan saat melintas dalam kawasan Pantai Losari adalah kesan nuansa kearifan lokal yang cukup kental sehingga mampu memberikan kesan tersendiri bagi wisatawan saat mengunjungi kawasan tersebut.

\section{Daftar Pustaka}

Naess, P. and Jensen, O. B (2004) Urban structure matters, even in a small town. 
Journal of Environmental Planning and Management 47(1), 35-37.

Wasilah \& Andi Hildayanti (2016) Kajian Pemanfaatan Ruang Kawasan Permukiman Tepian Kanal Pampang Kota Makassar berdasarkan Aktivitas Sosial Masyarakat. Prosiding Temu Ilmiah IPLBI 2016.

Fitroh, Syakir Kamil Ainul, Djamhur Hamid, and Luchman Hakim (2017) Pengaruh Atraksi Wisata dan Motivasi Wisatawan Terhadap Keputusan Berkunjung (Survei pada Pengunjung Wisata Alam Kawah Ijen). Jurnal Administrasi Bisnis 42(2), 18-25.

Akmila, Pindi Patana, and Yoes Soemaryono (2016) Strategi Pengelolaan Wisata Pantai Cemara Kembar Kabupaten Serdang Bedagai (Tourism Management Strategy of Cemara Kembar Beach in Serdang Bedagai District). Aquacoastmarine 14(4), 103-113.

Rizkhi and Imam Buchori (2014) Preferensi Pengunjung terhadap Daya Tarik Objek Wisata Teluk Palu di Kota Palu. Jurnal Pembangunan Wilayah \& Kota 10.4, 425439.

Wijono, Djoko (2017) Tingkat Kepuasan Pengunjung Obyek Wisata Pantai Kuwaru Sanden Bantul Yogyakarta. Jurnal Maksipreneur 4(1).

Hildayanti, Andi dan Wasilah (2017) Karakteristik Benteng Fort Rotterdam sebagai Urban Artefact Kota Makassar. Prosiding Seminar Heritage IPLBI 2017.

Spillane J.J (1987) Pariwisata Indonesia Sejarah dan Prospeknya. Yogyakarta: Kanisius.

Lau, gigi \& McKercher, Bob (2006) Understanding Tourist Movement Patterns in a Destination: A GIS Approach. Hongkong, http://www.jstor.org/discover/Understand ing-Tourist-Movement -Patterns

Santosa, Muhammad Ardli, Rasdyana Rasdyana, Ahmad Syauki, Lexsi Yosua Masseleng (2018) Kualitas Perancangan
Taman Benteng Roterdam Makassar. National Academic Journal of Architecture Vol. 5 No.1 pg.59-61 